\title{
Rainfall Intensity Analysis for Synoptic Stations in Northern Nigeria
}

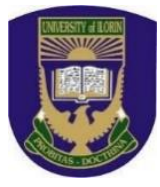

\author{
S. O. Oyegoke ${ }^{1}$, A. S. Adebanjo ${ }^{1 *}$, H. J. Ododo ${ }^{2}$ \\ ${ }^{1}$ Department of Civil Engineering, Afe Babalola University, Ado Ekiti, Nigeria. \\ ${ }^{2}$ Department of Civil Engineering, University of Lagos, Akoka, Nigeria.
}

ABSTRACT: With the large inter-annual variability of rainfall in Northern Nigeria, a zone subject to frequent dry spells which often result in severe and widespread droughts, the need for intense study of rainfall and accurate forecast of rainfall intensity duration frequency (IDF) curves cannot be over emphasized. The Intensity Duration Frequency relationship is a mathematical relationship between the rainfall intensity and rainfall duration for given return periods. Using a subset of the network of fifteen continuous auto recording rain gauges available in Northern Nigeria, a total of seven different time durations ranging from 12 minutes to 24 hours were developed for return periods of 2, 5, 10, 25, 50 and 100 years. The maximum data series so obtained was fitted to Gumbel's Extreme Value Type 1 distribution. Linear Regression Analysis was then used to obtain the intensity-duration relationships for the various locations from which Intensity-Duration Frequency (IDF) curves were generated using Microsoft Excel for various return periods.

KEYWORDS: Extreme rainfall, intensity, duration, frequency, Northern Nigeria.

[Received December 6, 2019, Revised July 16, 2020, Accepted August 8, 2020]

Print ISSN: 0189-9546 | Online ISSN: 2437-2110

\section{INTRODUCTION}

Statistical tools of analysis are normally employed to accurately capture historic rainfall events in order to plan adequately and to predict future rainfall intensity values that are used in designing hydrologic structures and for effective water resources management. Meanwhile, generally, there exists a wide variability in trends of rainfall as studied by researchers (Karl and Knight, 1998; Groisman et al.., 1999; Stone et al.., 2000; Zhang et al.., 2000; Osborn et al.., 2000; Whitfield et al.., 2002; Adamowski and Bougadis, 2003; Coulibaly and Shi, 2005; Ologunorisa and Tersoo, 2006; Vincent and Mekis, 2006; Markus et al.., 2007; Peterson et al.., 2008; Mailhot et al.., 2010; Udosen, 2012). It is extremely important to quantify and characterize whatever variability exists (Jeong, 2009). Information about this variability will help us understand the direction of future climate change (Franks, 2002).

The application of statistics and computing has made prediction of future rainfall intensities possible even though there are in most cases few available data, inhomogeneity of records (e.g. meteorological data may be the result of various incoherent climatological mechanisms) and climatological changes over long periods (Al-Mashidani et al.., 2009). These of course have called for the searches into what techniques to use in order to extract the maximum possible content from a set of inadequate rainfall data efficiently. Flood and rainfall being natural phenomena, are stochastic and therefore are treated as random variables which are elements of statistics of extremes particularly at the extreme cases of peak (maximum) value.

The interpolation and extrapolation of flood frequencies provide an easy answer on which practicing engineers base their designs (Al-Mashidani et al.., 2009) for the few available data. For the purpose of estimation, the Normal, Log Pearson type
III, the Gumbel extreme value distribution, and Log Normal distribution seem to have found a wider applicability than many other distributions which suffer inaccuracy in flood forecasting using rainfall data (Al-Mashidani et al.., 2009; Okonofua and Ogbeifun, 2013). Chow (1953) has suggested that Gumbel extreme value distribution method of analysis be used for the prediction of rainfall intensities.

Gumbel distribution is a stochastic generating structure that produces random outcomes which has found wide applications. It is one of the probability distributions used to model hydrologic parameters (Okonofua and Ogbeifun, 2013) and has been used for predicting extreme hydrological events (Zelenhasic, 1970; Haan, 1977; Shaw, 1983).

In recent times, evolutions in the engineering designs with rainfall data saw the use of series of generalized maps for several combinations of durations and return periods due to few available data collection stations.

Generally speaking, IDF curves are important as they are the basis on which the design and function of municipal water resources management infrastructures (such as storm sewers, overland drainage facilities, street curbs and gutters, basins, culverts, dikes, bridges, etc.) are done (Oyegoke et al.., 2017). According to Oyegoke and Sonuga (1983), Sonuga (1972) was the first to introduce the concept of maximum entropy to hydrologic frequency anlysis. Building on the work of Sonuga (1972), Jowitt (1979) undertook rigorous analysis that deduced the EV1 distribution from the principle of maximum entropy, when the given information relating to a random variable of unrestricted sense consists solely of the first two moments. For series best described by log normal distribution, Oyegoke $e t$ al. (1983) proved the superiority of the concept of maximum entropy for their use for frequency analysis. 
Oyebande (1982) published the first comprehensive nonempirical IDF studies for Nigeria with return periods of 50 or more years for 14 rainfall durations ranging from 12 minutes to 24 hours using extreme rainfall series for 35 meteorological stations in Nigeria.

Oyegoke and Oyebande (2008) further proved the relative advantage of the use of maximum entropy concept for evaluation of the parameters of the EV1 distribution while generating IDF relationships for several synoptic meteorological stations in Nigeria. Extensive work has been done by various researchers using EVI distribution to generate IDF curves for different regions of Nigeria (Oyebande, 1982; Oyegoke and Sonuga, 1983; Oyegoke et al..., 1983; Awokola. 2002; Salami and Sule, 2009; Okonkwo and Mbajiorgu, 2010; Nwoke and Nwaogazie, 2013; Akpan and Okoro, 2013; Ologhadien and Nwaogazie, 2017; Ogarekpe, 2014; and Oyegoke et al..., 2017) but mostly on Southern Nigeria.

The Northern Nigeria has received less attention. Earlier studies that involved some Northern states were the works of Oyebande (1982), and Oyegoke and Oyebande (2008); recent studies include Sule and Ige (2016), who fitted annual series of maximum daily rainfall into the Gumbel Extreme Value Type I distribution and rainfall depths for ten northern states. Olatunde and Adejoh (2017) also studied and analyzed the intensity, duration and frequency of rainstorms in Lokoja. This study presents the analysis of auto recorded extreme rainfall data for 15 synoptic stations in Northern Nigeria for seven time durations from 12 minutes to 24 hours as shown in Table 1.

\section{MATERIALS AND METHODS}

\section{A. Study Area}

Nigeria covers a land of surface area $900,000 \mathrm{~km}^{2}$, lies between longitudes $3^{\circ}$ and $5^{\circ}$ East and latitudes $4^{\circ}$ and $14^{\circ}$ North with North-South extent of about $1,050 \mathrm{~km}$ and its maximum East-West extent covers about $1,150 \mathrm{~km}$. The country is generally put in two geographical zones, Southern and Northern Nigeria (Figure 1). Both are well drained with a close network of rivers and streams that are continuously sustained by high intense annual rainfall which is generally any or combination of orographic, convective, and tropical rainfall. Northern Nigerian states like Adamawa and Jos experience orographic rainfall due to the presence of hills, convective rainfall and cyclonic rainfall also occur in some northern states.

\section{B.Data Collection}

Rainfall measurements with automatic recording rain gauges were obtained from Nigerian Meteorological Agency, NIMET, from which the series of maximum annual values for $12 \mathrm{~min}, 24 \mathrm{~min}, 1 \mathrm{hr}, 3 \mathrm{hr}, 6 \mathrm{hr}, 12 \mathrm{hr}$ and $24 \mathrm{hr}$ durations were collated and analyzed for 15 synoptic Stations in Northern Nigeria. The range of data available for these stations are is presented in Table 1.

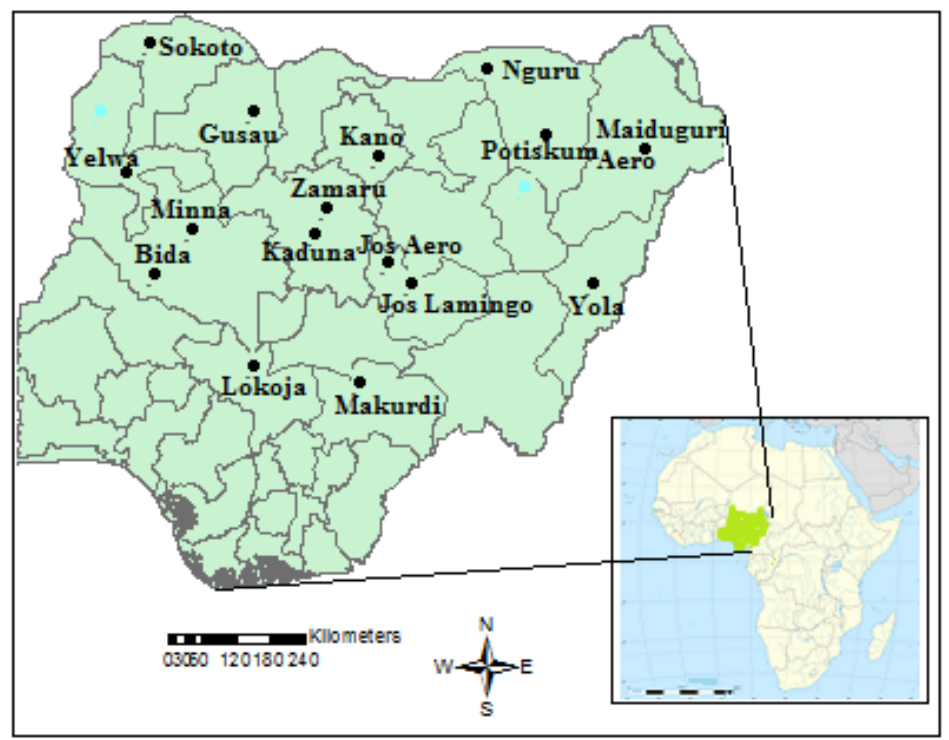

Figure 1: The rainfall stations used for the study.

Table 1: Meteorological Stations with length of period of rainfall data.

\begin{tabular}{lcl}
\hline \multicolumn{1}{c}{ Station names } & $\begin{array}{c}\text { Length of } \\
\text { Record (years) }\end{array}$ & \multicolumn{1}{c}{ Period } \\
\hline Sokoto & 14 & $1956-1969$ \\
Yelwa & 17 & $1960-1966,1969-1978$ \\
Kano & 19 & $1951-1960,1967-1975$ \\
Samaru & 14 & $1955-1964,1967-1970$ \\
Gusau & 11 & $1956-1965$, \\
Lokoja & 21 & $1956-1965,1967-1968$ \\
& & $1970-1978$ \\
Minna & 16 & $1956-1962,1967-1975$ \\
Jos Lamingo & 11 & $1960-1969$, \\
Kaduna & 23 & $1952-1962,1967-1978$ \\
Jos Aero & 27 & $1952-1978$ \\
Maiduguri Aero & 17 & $1956-1962,1964-1968$, \\
& & $1970-1971,1973-1978$ \\
Potiskum & 17 & $1956-1966,1968-1973$ \\
Nguru & 14 & $1960-1973$ \\
Yola & 15 & $1956-1966,1969-1973$ \\
Makurdi & 19 & $1956-1974$ \\
Sokoto & 14 & $1956-1969$ \\
\hline
\end{tabular}

\section{Gumbel Distribution}

Return period is the length of years for which an event is expected to repeat itself i.e. an n-year event occurring at least once in the next $\mathrm{n}$ years. It is a vital tool in determining the probability of occurrence of a hydrologic event. Elementary probability theory shows that, there is a good chance that the nyear event will occur at least once before $n$ years have elapsed.

According to Gumbel (1958), the probability of occurrence of an event equal to or longer than value $X_{o}$ is expressed as (Shaw, 1983):

$$
P\left(X \geq X_{0}\right)=f(x)=\exp \{-\exp [-\alpha(x-v)]\}
$$

For a recurrence interval, $T$ and the variate, $x$,

$$
\frac{1}{T}=1-f(x)=1-\exp \{-\exp [-\alpha(x-v)]\}
$$




$$
x=U-\frac{1}{\alpha} \ln \left(\ln \frac{T}{T-1}\right)
$$

Giving the general frequency equation as

$$
x=\bar{x}+K \cdot \mathrm{S}_{x}
$$

where $S_{x}$ is standard deviation, $\bar{x}$ is the mean for $x$ and $K$ is the frequency factor

$$
\begin{aligned}
\bar{x} & =u+\frac{0.5772}{\alpha} \\
S^{2} & =\text { variance }=\frac{\pi^{2}}{6 \alpha^{2}}
\end{aligned}
$$

Substituting for $\bar{x}, x$ and $\mathrm{S}$ in the frequency equation and solving for $K$.

We have;

$$
K=\frac{-\sqrt{6}}{\pi}\left(0.5772+\ln \left[\ln \frac{T}{T-1}\right]\right)
$$

The steps given by Chow et al... (1988) for estimating the design flood for any return period using Gumbel's distribution were used. Annual maximum rainfall data for the various stations were assembled for a period of several years at durations of 12 mins, 24 mins, $1 \mathrm{hr}$, 3hrs, 6hrs, 12hrs, and 24hrs; mean, $\bar{x}$ and standard deviation, $S_{x}$ of the maximum rainfall data for the $n$ number of years and for each of these durations are computed. Coefficients A and B were then obtained by linear ordinary least squares regression analysis and are as presented in Table 2, first row is A and second row B; can be used to compute the intensity of rainfall using a model of the form

$$
i=\frac{A}{t+B},
$$

taking the intensity as $i$.

The rainfall data for the various return periods can then be used to fit the intensity-duration frequency curves.

The above expression can then be expressed in linear form as

$$
\frac{1}{i}=\frac{t}{A}+\frac{B}{A}
$$

Comparing with straight line equation

$$
Y=a_{1} X+a_{0} \text {, }
$$

The regression of $\frac{1}{i}$ versus $t$ will give values of $A$ and $B$, first by making $\frac{1}{i}=\mathrm{Y}$ and $t=X$, thus $a_{0}=\frac{B}{A}$ and $a_{1}=\frac{1}{A}$, where,

$$
\begin{aligned}
& a_{0}=\frac{\sum Y \sum X^{2}-\sum X \sum X Y}{n \sum X^{2}-\left(\sum X\right)^{2}} \\
& a_{1}=\frac{n \sum X Y-\sum X \sum Y}{n \sum X^{2}-\left(\sum X\right)^{2}}
\end{aligned}
$$

\begin{tabular}{|c|c|c|c|c|c|c|c|c|}
\hline \multirow[t]{2}{*}{$\mathbf{S} / \mathbf{N}$} & \multirow[t]{2}{*}{ Station } & \multicolumn{7}{|c|}{ Return Periods } \\
\hline & & 1 & 2 & 5 & 10 & 25 & 50 & 100 \\
\hline \multirow[t]{2}{*}{1} & Sokoto & 1792.4 & 3154.1 & 3967.1 & 4505.3 & 5185.3 & & \\
\hline & & 42 & 37.7 & 36.9 & 36.6 & 36.4 & & \\
\hline \multirow[t]{2}{*}{2} & Yelwa & 2128.3 & 3317.1 & 4029.7 & 4501.7 & 5098.4 & & \\
\hline & & 17 & 17.9 & 19 & 19.8 & 20.6 & & \\
\hline \multirow[t]{2}{*}{3} & Kano & & 3634 & 5445 & 6647 & 8168 & 9298 & \\
\hline & & & 27 & 35 & 38 & 41 & 43 & \\
\hline \multirow[t]{2}{*}{4} & Samaru & 2128.3 & 1423.4 & 4081.2 & 5682.9 & 6746 & & \\
\hline & & 17 & 29.3 & 39.2 & 43.2 & 45.2 & & \\
\hline \multirow[t]{2}{*}{5} & Gusau & & 3656.8 & 4453.8 & 4981.8 & 5649.2 & & \\
\hline & & & 24.6 & 30.6 & 33.7 & 36.9 & & \\
\hline \multirow[t]{2}{*}{6} & Lokoja & 2076.1 & 4103.3 & 5314 & 6115.5 & 7128.3 & & \\
\hline & & 36.7 & 25.8 & 23.8 & 23 & 22.2 & & \\
\hline \multirow[t]{2}{*}{7} & Minna & 1230 & 5367 & 7788 & 9391 & 11417 & & \\
\hline & & 51.4 & 48 & 57 & 61 & 65 & & \\
\hline \multirow[t]{2}{*}{8} & Jos Lamingo & 2877.3 & 4335.4 & 5229.6 & 5823.4 & 6574.6 & & \\
\hline & & 96 & 47.5 & 37.6 & 33.2 & 29 & & \\
\hline \multirow[t]{2}{*}{9} & Kaduna & 2289.1 & 3915.6 & 4888.6 & 5533 & 6347.2 & 6951.2 & 7550.8 \\
\hline & & 45.9 & 32.3 & 28.9 & 27.4 & 25.9 & 25.1 & 24.4 \\
\hline \multirow[t]{2}{*}{10} & Jos Aero & 2044.7 & 3689.6 & 4673.9 & 5325.8 & 6149.6 & 6760.8 & 7367.6 \\
\hline & & 23.5 & 40.5 & 45.6 & 48.1 & 50.5 & 52 & 53.2 \\
\hline \multirow[t]{2}{*}{11} & Maiduguri Aero & 1623.1 & 3664.3 & 4889.8 & 5702.2 & 6729.6 & & \\
\hline & & -6.3 & 24.7 & 33.4 & 37.5 & 41.6 & & \\
\hline \multirow[t]{2}{*}{12} & Potiskum & & 1914.4 & 3544.1 & 4519.5 & 5165.5 & 5981.7 & \\
\hline & & & 32.3 & 18.4 & 15.4 & 14 & 12.8 & \\
\hline \multirow[t]{2}{*}{13} & Nguru & & 2649.7 & 3685.8 & 4372 & 5239.3 & 10340 & 11258 \\
\hline & & & 18.9 & 22.8 & 24.5 & 26 & 52 & 53 \\
\hline \multirow[t]{2}{*}{14} & Yola & 1811.2 & 4179.5 & 5599.8 & 6540.9 & 8613.1 & & \\
\hline & & 27.9 & 25.5 & 26 & 26.3 & 26.9 & & \\
\hline \multirow[t]{2}{*}{15} & Makurdi & 2995.2 & 4754.6 & 5806.8 & 6503.6 & 7384 & 8037.1 & \\
\hline & & 30 & 28.2 & 27.7 & 27.5 & 27.3 & 27.2 & \\
\hline
\end{tabular}

\section{RESULTS AND DISCUSSION}

Using the procedures listed above for the rainfall intensity data from the 15 meteorological stations, IDF curves were plotted for the intensity, $I$ against return period, $t$ on the log-log graph as shown in Figure 2.

Table 2: Coefficients of Regression for the rainfall stations used for the study. 


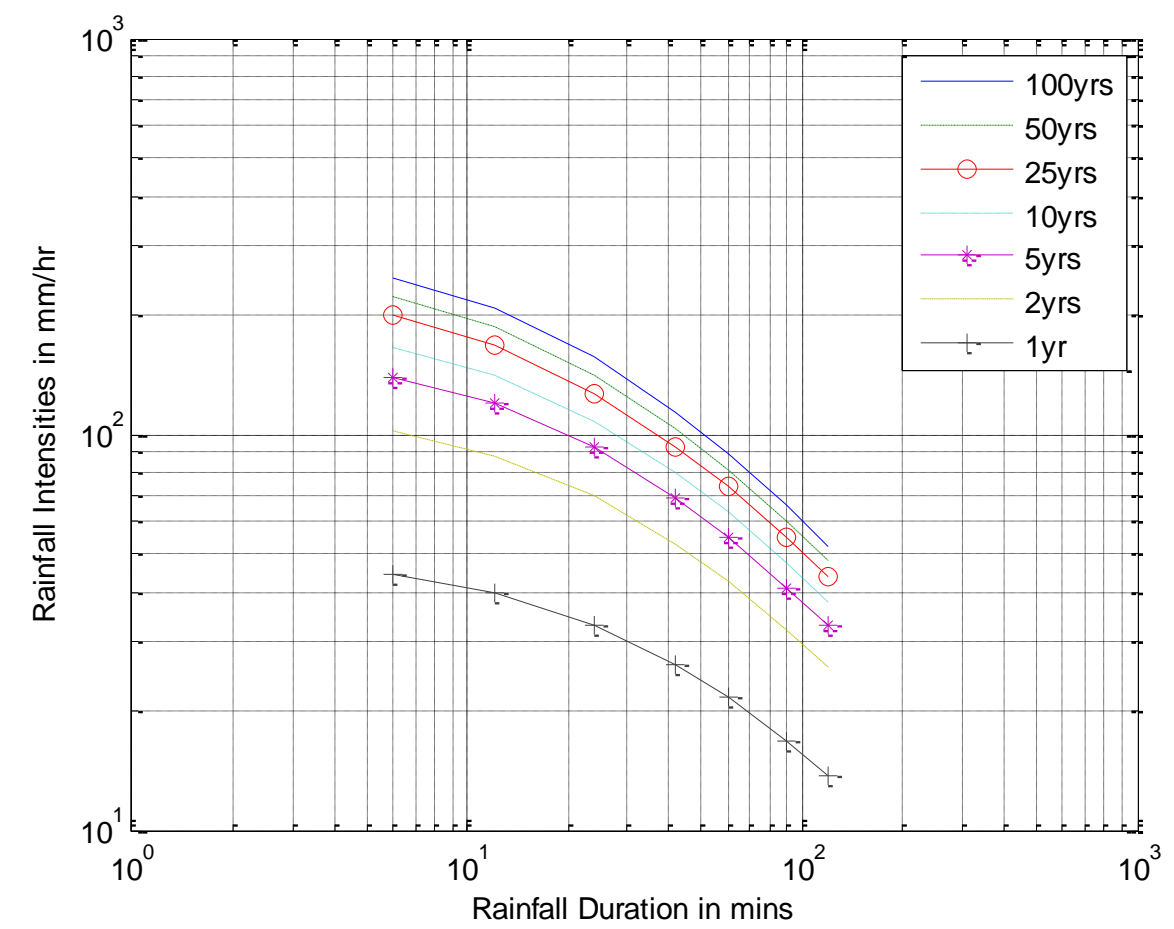

Figure 2: IDF curve for Kaduna.

Table 3: Relative intensities for different rainfall duration at 5-year return period in Potiskum.

\begin{tabular}{cc}
\hline $\begin{array}{c}\text { Rainfall duration } \\
(\mathbf{m i n})\end{array}$ & $\mathbf{I}(\mathbf{m m} / \mathbf{h r})$ \\
\hline 3 & 192 \\
10 & 190.9 \\
15 & 190 \\
30 & 187.5 \\
60 & 182.6 \\
\hline
\end{tabular}

Table 4: Relative intensities for different rainfall duration at 10-year return period in Potiskum.

\begin{tabular}{cc}
\hline $\begin{array}{c}\text { Rainfall duration } \\
(\mathbf{m i n})\end{array}$ & $\mathbf{I}(\mathbf{m m} / \mathbf{h r})$ \\
\hline 3 & 367.7 \\
10 & 364.6 \\
15 & 362.5 \\
30 & 356.2 \\
60 & 344.4 \\
\hline
\end{tabular}

Generally, while designing hydraulic structures in a given area, peak surface runoff is estimated from methods such as the rational method using the extreme rainfall data (rainfall that lasted 30 mins or less) for the area. This will capture such disasters like flood that have capacity to hydraulically overstress structures. Rainfall Intensity-Duration-Frequency (IDF) relationships are presented as tables and/or curves which serve as guide for the description of location rainfall and in the estimation of runoffs for design of hydraulic structures.
The coefficients of regression for developing IDFs for return periods of 1 year, 2 years, 5 years, 10 years, 25 years and 50 years where possible for the various synoptic stations considered in this study are as presented in Table 2 and Figure 2 is an example for Kaduna.

As can be observed on Table 3 and Table 4, intensities of rainfall as are obtainable from the IDF curves and formulae increase with increasing length of return periods for all the stations. It is therefore important to plan design of large hydraulic structures with high length of return period of storm. Areas around coasts and rivers should expect increasing rise in flood that results from events of rainfall.

It can be seen also that for given length of return period, intensity of rainfall decreases with increasing duration of rainfall. This implies an increasing trend in expected rainfall intensity as is expected for extreme (short duration) rainfall. This program satisfactorily performs the prediction of rainfall intensity and will therefore be useful in the development of a database for the long term analysis of rainfall in northern Nigeria and in the generation of IDF curves for use in the hydrologic design of hydraulic structures and for other related purposes.

\section{CONCLUSION}

This study has presented the concepts of using Gumbel's Extreme Value Type 1 distribution as a predictive tool for the expected rainfall intensity of a given place. It has been simplified for determining the value of the coefficient of 
variation, $\mathrm{A}$ and $\mathrm{B}$ of the given data from which rainfall intensity for a given return period is normally obtained. The values so obtained are useful in the design of hydraulic structures such as storm water drains, culverts, dams and reservoirs with a view to protecting lives and properties along the course of flow or at the downstream of a river.

The findings in this study have shown that extreme rainfall event is responsible for high intensity rainfall which could result to higher flood than longer duration rainfalls. Intensity of rainfall also increases with longer return periods of rainfall.

\section{ACKNOWLEDGEMENTS}

The authors acknowledge the moral and invaluable support of Prof Emeritus Lekan Oyebande and Engrs Dipo Soyoola and Ayodele Dina.

\section{REFERENCES}

Adamowski, K. and Bougadis, J. (2003). Detection of trends in annual extreme rainfall. Hydrological Processes, 17(18): 3547-3560. https://doi.org/10.1002/hyp.1353

Akpan, S. U. and Okoro, B. C. (2013). Developing Rainfall Intensity-Duration-Frequency Models for Calabar City, South-South, Nigeria. American Journal of Engineering Research, 2(6): 19-24.

Al-Mashidani, G.; B. Pande; B. Lal and F. M. Mujda. (2009). A simple version of Gumbel's method for flood estimation, Hydrological Sciences Bulletin, 23(3): 373-380. https://doi.org/10.1080/02626667809491810

Awokola, O. S. (2002). Regional Rainfall IntensityDuration Frequency (IDF) Analysis for Southern Nigeria. Nigerian Journal of Science. 36(1): $17-27$.

Bates, B. C.; Z. W. Kundzewicz; S. Wu and J. P. Palutikof. (Eds.) (2008). Climate Change and Water. Geneva: Technical Paper of the Intergovernmental Panel on Climate Change, IPCC Secretariat, 210.

Chow, V. T. (1953). Frequency Analysis of Hydrologic Data with Special Application to Rainfall Intensities. University of Illinois. Engineering Experiment Station. Bulletin; No. 414.

Chow, V. T.; D. R. Maidment and L. W. Mays. (1988). Applied Hydrology. McGraw Hill Book Company, Singapore.

Coulibaly, P. and Shi, X. (2005). Identification of the Effect of Climate Change on Future Design Standards of Drainage Infrastructure in Ontario - Highway Infrastructure Innovation Funding (HIIFP) Program. HIIFP-022, Report to Ontario Ministry of Transportation, Hamilton, Ontario.

Franks, S. W. (2002). Assessing hydrological change: deterministic general circulation models or spurious solar correlation? Hydrological Processes, 16(2): 559-564. https://doi.org/10.1002/hyp.600

Groisman, P. Y.; T. R. Karl; R. D. Easterling; W. R. Knight and F. P. Jamason. (1999). Changes in the probability of heavy precipitation: Important indicators of climatic change. In: Karl T.R., Nicholls N., Ghazi A. (eds) Weather and Climate
Extremes. Springer, Dordrecht, $243-283$. https://doi.org/10.1007/978-94-015-9265-9_15

Gumbel, E. J. (1958). Statistics of Extremes. Colombia University Press, New York, 375.

Haan, C. T. (1977). Statistical Methods in Hydrology, Iowa State University Press, Iowa, 516.

Jeong, D. I. (2009). Trends and multi-decadal variability of annual maximum precipitation for Seoul, South Korea, Urban Water Journal, 6(6): 431-439. https://doi.org/10.1080/15730620903242832.

Jowitt, P. W. (1979). The extreme-value type - 1 distribution and the principle of maximum entropy, J. Hydrol., 42(1-2): 23-38. https://doi.org/10.1016/0022-1694(79)90004-0

Karl, T. R. and Knight, R. W. (1998). Secular trends of precipitation amount, frequency, and intensity in the United States. Bulletin of the American Meteorological Society, 79(2): 231-241. 0477(1998)079<0231:STOPAF>2.0.CO;2 https://doi.org/10.1175/1520-

Mailhot, A.; A. Kingumbi; G. Talbot and A. Poulin. (2010). Future changes in intensity and seasonal pattern of occurrence of daily and multi-day annual maximum precipitation over Canada. Journal of Hydrology, 388(3-4): 173-185. https://doi.org/10.1016/j.jhydrol.2010.04.038

Markus, M.; J. R. Angel; L. Yang and M. I. Hejazi. (2007). Changing estimates of design precipitation in Northeastern Illinois: Comparison between different sources and sensitivity analysis. Journal of Hydrology, 347(1-2), 211222. https://doi.org/10.1016/j.jhydrol.2007.09.024

Nwoke, H. U. and Nwaogazie, I. L. (2013). Rainfall Intensity Duration Frequency Regime for Onitsha city. American Journal of Engineering Research (AJER). 2(6): 1924.

Ogarekpe, N. (2014). Development and Comparison of Different Intensity Duration Frequency Models for Calabar, Nigeria. Nigerian Journal of Technology, 33(1): 33-42.

Okonkwo, G. and Mbajiorgu, C. C. (2010). Rainfall intensity-duration-frequency analysis for Southeastern Nigeria. Agricultural Engineering International: CIGR Journal, 12(1): $22-30$.

Okonofua, S. and Ogbeifun, P. (2013). Flood Frequency Analysis of Osse River Using Gumbel's Distribution. Civil and Environmental Research, ISSN 2224-5790 (Paper) ISSN 22250514 (Online), 3(10), 55-60.

Olatunde, A. F. and Adejoh, I. (2017). Intensity Duration and Frequency of Rainstorms in Lokoja. Science World Journal, 12(2): 36-40.

Ologhadien, I. and Nwaogazie, I. L. (2014). Comparative Analysis of Rainfall IDF equation types for Predicting Rainfall Intensity in Southern Nigeria. Nigerian Journal of Technology, 36(4): 296-1302. http://dx.doi.org/10.4314/njt.v3614.40

Ologunorisa, T. E. and Tersoo, T. (2006). The Changing Rainfall Pattern and Its Implication for Flood Frequency in Makurdi, Northern Nigeria. Journal of Applied Science and Environmental Management, 10(3): 97-102.

Osborn, T. J.; M. Hulme; P. D. Jones and T. A. Bassett. (2000). Observed trends in the daily intensity of United 
Kingdom precipitation. International Journal of Climatology, 20(4): 347-364.

Oyebande, L. (1982). Deriving Rainfall Intensity Duration Frequency Estimates for Regions with Inadequate Data. Hydrological Science Journal, 27(3): 353-367. https://doi.org/10.1080/02626668209491115

Oyegoke, E. S.; J. O. Sonuga and G. A. Akpoji. (1983). The Principle of Maximum Entropy for Parameter Estimation of Statistical Distributions. A.S.C.E. Engineering Mechanics Specialty Conference, West Lafayette, Indiana, U.S.A., 899902.

Oyegoke, E. S. and Sonuga, J. O. (1983). A new technique for the analysis of extreme rainfall with application to Lagos Metropolis, Nigeria. Nordic Hydrol., Denmark, 14(3): 127-138.

Oyegoke, S. O. and Oyebande, L. (2008). A new technique for Analysis of Extreme Rainfall for Nigeria. Environmental Research Journal, 2(1): 7-14.

Oyegoke S. O.; A. S. Adebanjo; E. O. Ajani and J. T. Jegede. (2017). Analysis of Rainfall Intensity for Southern Nigeria. Journal of Engineering Research, 22(1): 108-119.

Peterson, T. C.; X. Zhang; M. Brunet-India and J. L. Vázquez-Aguirre. (2008). Changes in North American extremes derived from daily weather data. Journal of Geophysical Research, 113(D07113): 1-9. https://doi.org/10.1029/2007JD009453.

Salami, A. W. and Sule, B. F. (2009). Establishment of rainfall intensity model for selected townsin Nigeria based on Sherman equation. 1st Annual Civil Engineering Conference, University of Ilorin, Nigeria, 26-28.

Shaw, E. M. (1983). Hydrology in Practice. Van Nostrand Reinhold, UK.
Sonuga, J. O. (1972). Principle of Maximum Entropy in Hydrologic Frequency Analysis, J. Hydrol., 17(1): 77-191.

Stone, D. A.; A. J. Weaver and F. W. Zwiers. (2000). Trends in Canadian Precipitation Intensity. Atmosphere-Ocean, 38(2): 321-347. https://doi.org/10.1080/07055900.2000.9649651

Sule, B. F. and Ige, I. (2016). Synthesis of Isopluvial Maps for Nigeria using IDF Equations Derived from Daily Rainfall Data. Journal of Scientific and Engineering Research, 3(3): 505-514.

Udosen, C. (2012). Rainfall Trends in Uyo-Akwa Ibom State and its Implication on Urban Flooding. Medwell Journals, 7(1): 79-85. https://doi.org/10.3923/jeasci.2012.79.85

Vincent, L. and Mekis, E. (2006). Changes in daily and extreme temperature and precipitation indices for Canada over the twentieth century. Atmosphere-Ocean, 44(2): 177-193. http://dx.doi.org/10.3137/ao.440205

Whitfield, P. H.; K. Bodtker and A. J. Cannon. (2002). Recent variations in seasonality of temperature and precipitation in Canada, 1976-1995. International Journal of Climatology, 22(13): $\quad 1617-\quad 1644$. https://doi.org/10.1002/joc.813

Zelenhasic, E. (1970). Theoretical Probability Distributions for Flood Peaks. Colorado University Press, Colorado.

Zhang, X.; L. A. Vincent; W. D. Hogg and A. Niitsoo. (2000). Temperature and precipitation trends in Canada during the 20th century. Atmosphere-Ocean, 38(3): 395-429. http://dx.doi.org/10.1080/07055900.2000.9649654 